\title{
EPILITHIC DIATOM-BASED ECOLOGICAL ASSESSMENT IN TAŞMANLI POND (SINOP, TURKEY)
}

\author{
Fatih GÜMÜŞ ${ }^{1 *}$, Arif GÖNÜLOL ${ }^{2}$ \\ ${ }^{1}$ Sinop University, Faculty of Art and Science, Department of Biology, Sinop, TURKEY \\ ${ }^{2}$ Ondokuz Mayıs University, Faculty of Art and Science, Department of Biology, Samsun, TURKEY \\ *Corresponding author: e-mail: lakustrin@gmail.com \\ Cite this article as: \\ Gümüş F. \& Gönülol A. 2018. Epilithic Diatom-Based Ecological Assessment in Taşmanlı Pond (Sinop, Turkey). Trakya Univ J Nat Sci, 19(1): 71- \\ 76, DOI: $10.23902 /$ trkjnat.339417
}

Received: 22 September 2017, Accepted: 21 March 2018, Online First: 30 March 2018, Published: 15 April 2018

\begin{abstract}
The common goal of the Water Framework Directive (WFD) published by The European Parliament and European Council and the Regulation on the Management of Surface Water Quality Directive (RMSWQ) published by the Republic of Turkey, Ministry of Forestry and Water Affairs, is to provide all water bodies to achieve a fine ecological status. These directives require the use of relevant biological quality elements and diatoms constitute an important group within these elements. The use of diatom based indices for assessing ecological conditions in inland water systems is increasing day by day. The current study was performed with the aim of determination of the ecological status of the Taşmanlı Pond based on epilithic diatoms, physico-chemical parameters and to estimate pond water quality using diatom indices. For this purpose, epilithic diatom and water samples were collected from 3 stations in the pond in monthly intervals from March 2008 to March 2009. The identifications of the sampled revealed presence of a total of 46 taxa in the sampled stations. Achnanthidium minutissimum (Kützing) Czarnecki, Nitzschia acicularis (Kützing) W. Smith, Navicula cincta (Ehrenberg) Ralfs in Pritchard and Navicula cryptocephala Kützing were the dominant taxa in all stations. According to Regulation on the Management of Surface Water Quality directive, the pond water was classified as III-IV quality class and trophic status changed from mesotrophic to eutrophic. Significant correlation was determined between LTDI (Lake Trophic Diatom Index) and EQR (Ecological Quality Ratio). The values of LTDI and EQR indicate that, pond water has class III (poor, moderately polluted site) water quality.
\end{abstract}

Key words: Epilithic, Diatom, LTDI, EQR, Pond, Taşmanl1, Sinop, Turkey.

Özet: Avrupa Parlementosu ve Avrupa Birliği tarafindan yayınlanan Su Çerçeve Direktifi (WFD) ve Türkiye'de "Orman ve Su İşleri Bakanlığı, Su Yönetimi Genel Müdürlüğü” tarafından yayınlanan "Yüzey Suları Su Kalite Yönetmeliği”nin ortak hedefi, tüm su kütlelerinin iyi bir ekolojik statüye ulaşmasıdır. Bu yönetmelikler, amaca uygun biyolojik kalite öğelerini kullanmayı gerektirmektedir ve diyatomeler bu öğeler içerisinde oldukça önemli bir grubu oluşturmaktadır. Diyatome temelli indislerin içsu kütlelerinde ekolojik parametrelerin belirlenmesi amacı ile kullanımı günden güne artış göstermektedir. Bu çalışmada, Taşmanlı Göleti'nin ekolojik durumunun değerlendirilmesinde epilitik diyatomelerin, fizikokimyasal parametrelerin ve diyatome indislerinin ekolojik kalitenin belirlenmesinde, bir araç olarak test edilmesi amaçlanmıştır. Bu nedenle, Mart 2008 - Mart 2009 tarihleri arasında göletten alınan diyatome ve su örnekleri analizleri sonucunda, toplam 46 takson gözlenmiş̧tir. Bunlardan Achnanthidium minutissimum (Kützing) Czarnecki, Nitzschia acicularis (Kützing) W.Smith., Navicula cincta (Ehrenberg.) Ralfs in Pritchard, Navicula cryptocephala Kützing tüm istasyonlardaki baskın türlerdir. Yapılan fizikokimyasal testler sonucu gölet suyu "Yüzeysel Su Kalitesi Yönetmeliği” ne göre III-IV kalite sınıfı olarak sınıflandırılmış ve trofik durumu mezotrofiden ötrofiye doğru değişmiştir. LTDI (Göl Trofik Diatom İndeksi) ve EQR (Ekolojik Kalite Oranı) değerleri gölet suyunun sınıf III (tamamen kirli alan) su kalitesine sahip olduğunu göstermektedir.

\section{Introduction}

Water is vital for any type of life on earth. The world contains aquatic and terrestrial ecosystems that are in very close contact with each other resulting in a delicate balance. The continuity of life is directly related to the continuity of this dynamic ecosystem interaction. Moreover, the continuity of socioeconomic inputs for humans is realized by the continuity of this system. Algae are primary producers of aquatic ecosystems and ensure the continuity of the systems they are involved in. This essential component creates the natural energy inputs of aquatic ecosystems and forms the most fragile link.

Aquatic systems, freshwater ecosystems in particular, are under a constant and strong pressure of human related activities (Gümüş 2010). Therefore, protection of natural water resources and the dominance of aquatic systems is one of the most important elements to be used in determination of future standard of life quality. Small physico-chemical changes in water initiate a chain 
reaction that affects both algae and our life quality. Phytobenthos is one of the biological quality elements that must be contained in The Water Framework Directive (WFD, "Directive 2000/60/EC" The European Parliament and European Council 2000) assessments of ecological status of freshwaters and diatoms are good environmental indicators and are often the main component of phytobenthos (Della Bella et al. 2007). Although diatoms are one of the important components of phytobenthos in aquatic systems, only some countries have yielded WFDcompliant phytobenthos tools specifically for lakes (Bennion et al. 2014). Diatoms are also taken into account as key organisms used as biological indicators in ecological quality analysis. Diatom-based water quality evaluation is a new process for Turkey and the first studies have begun after 2000s. Some of these studies were performed in Antalya River basin (Kalyoncu 2002, Solak et al. 2007a, Kalyoncu et al. 2009), Büyük Menderes River basin (Barlas et al. 2001, 2002, Solak et al. 2007b), Fırat River basin (Gürbüz \& Kıvrak 2002), Kızılırmak River basin (Akbulut et al. 2010), Sakarya River basin (Solak et al. 2009, Solak 2011) and Susurluk River basin (Dalkıran et al. 2008, Karacaoğlu et al. 2008, Solak et al. 2011, Solak \& Acs 2011), showing that no study has been performed so far in Taşmanlı Pond on the subject of diatom-based water quality evaluation.

The present study was performed in order to determine the ecological status of Taşmanlı Pond based on epilithic diatoms and to estimate pond water quality using diatom indices.

\section{Materials and Methods}

\section{$\underline{\text { Study Area }}$}

Taşmanl 1 Pond $\left(41^{\circ} 54^{\prime} \mathrm{N}, 35^{\circ} 02^{\prime} \mathrm{E}\right)$ is located in the southern part of Sinop (Fig. 1) and covers an area of
222.000 square meters. The maximum depth of the pond is $15 \mathrm{~m}$ and the minimum is $3-4 \mathrm{~m}$. The pond was constructed in 1977 by the General Directorate of State Hydraulic Works (DSI) for irrigation and it does not freeze in winter. The pond is free of industrial waste water discharge and juvenile common carp (Cyprinus carpio Linnaeus) were released a few times to the pond with the aim of breeding. Forest and scrub vegetation is observed in the drainage basin of the pond.

\section{Sampling and Chemical Analysis}

The samples were collected monthly from March 2008 to March 2009. Epilithic samples were collected from the stones by brushing, brought to the laboratory in plastic cups then preserved in $4 \%$ formalin solution. Diatoms were cleaned using hydrogen peroxide $\left(\mathrm{H}_{2} \mathrm{O}_{2}\right)$ and diluted hydrochloric acid (3\%) was added to purify calcium carbonate (Renberg 1990). After cleaning, the diatom frustules were washed with distilled water and rinsed. Clean diatom frustules were mounted in a synthetic resin (Naphrax). Diatom species were identified according to Krammer \& Lange-Bertalot (1991a, 1991b, 1999a, 1999b), Round et al. (1990) and Sims (1996). Relative abundances of diatom species were evaluated by counting 300 valves per sample (Round 1953). Identified species were checked in algae databases and necessary taxonomic corrections were made (Guiry \& Guiry 2017, Gönülol 2017). The author names were abbreviated according to Brummit \& Powell (1992).

The surface water samples for physico-chemical analysis in laboratory were taken from all stations using plastic bottles. Environmental parameters such as dissolved oxygen of the water, temperature were measured in field with portable instruments.

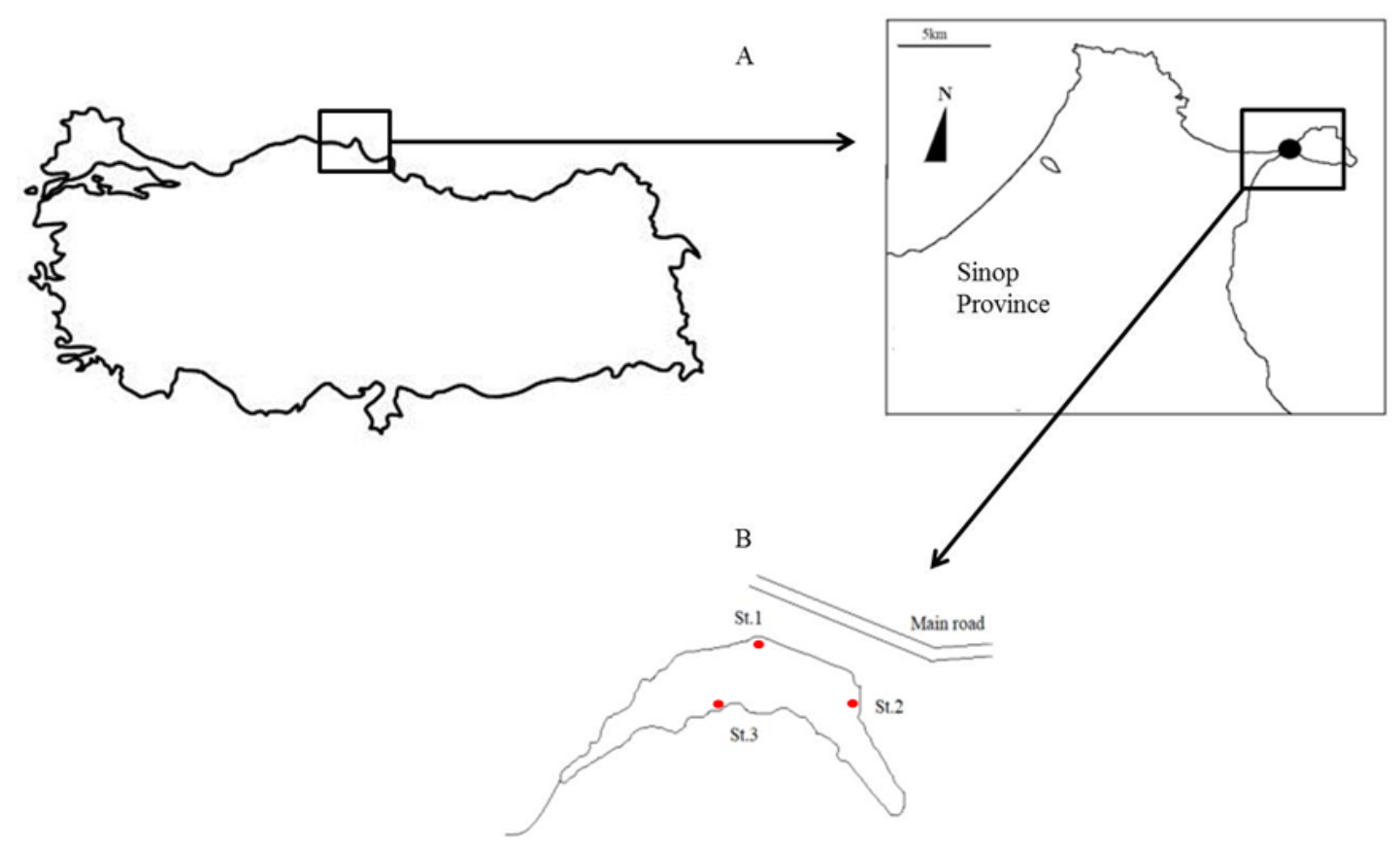

Fig. 1. A) The maps showing locations of Sinop in Turkey (on the top left) and Taşmanlı Pond in Sinop (on the top right) and B) the schematic representations of the locations of the stations in the pond. 
Chemical analysis were carried out according to APHA protocols (APHA 1998) and contained nutrients and ions such as chloride, nitrates, alkalinity, silica and phosphates. The water conductivity and $\mathrm{pH}$ were measured using a portable digital $\mathrm{pH}$ meter (Hach $\left.{ }^{\circ} H Q 40 d\right)$. The temperature and the dissolved oxygen values -as environmental parameters- of the water samples were measured in the filed using a portable handheld dissolved oxygen and temperature system

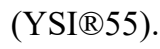

\section{$\underline{\text { Data Analysis }}$}

The average values and standard errors of all physicochemical analysis were computed using "Microsoft ${ }^{\circledR}$ Office Excel 2003". Diatom diversity " $\mathrm{H}^{\prime}$ " (Shannon \& Weaver 1949) and evenness "J'" (Pielou 1975) indexes were computed with Primer5 software (Clarke 1993). Trophic diatom indices were computed by two different softwares; i) Trophic Diatom Index for Lakes (TDIL) was computed with the DILSTORE software (Hajnal et al. 2009) and ii) Lake Trophic Diatom indices (LTDI) developed based on modification of the trophic diatom index (TDI) (Kelly \& Whitton 1995) and Ecological Quality Ratio (EQR) were computed with the DARLEQII Software (WFD-UKTAG 2014).

\section{Results}

The identifications of the collected material showed that a total 46 taxa were present in the sampled stations of the pond (Table 1). The numerical distributions of the taxa with respect to the sampling months were given in Figure 2. Achnanthidium minutissimum (Kützing) Czarnecki, Nitzschia acicularis (Kützing) W.Smith, Navicula cincta (Ehrenberg) Ralfs in Pritchard and Navicula cryptocephala Kützing were the dominant taxa in all stations. The lowest nitrate value was measured in March 2008 with $1.17 \mathrm{mgL}^{-1}$ in St1 and the highest value was measured in August 2008 with $1.46 \mathrm{mgL}^{-1}$ in St2. The lowest phosphate value was measured in March 2009 in St2 with $0.14 \mathrm{mgL}^{-1}$ and the highest value was measured in August 2008 in St 1 with $2.97 \mathrm{mgL}^{-1}$. The lowest value of silica was recorded in May 2008 in St3 with $0.09 \mathrm{mgL}^{-}$ ${ }^{1}$ and the highest value was measured in March 2009 in St1 with $3.10 \mathrm{mgL}^{-1}$. Total alkalinity ranged from 12.20 to $109 \mathrm{mgL}^{-1} \mathrm{CaCO}_{3}$. Maximum, minimum and average values and the standard deviations of measured physicochemical variables were given in (Table 2). The lowest values of Shannon-Weaver and Evenness indices for all three stations were calculated in May. Although the numbers of sampled individuals for the identified taxa were higher than other months, all stations were represented with a less diverse species moiety in May. In particular, Pantocsekiella ocellata and Achnanthidium minutissimum reached the dominant position by reaching their highest numbers in this month. This is also consistent with the low index values observed in May. Diversity $\left(\mathrm{H}^{\prime}\right)$ and evenness $\left(\mathrm{J}^{\prime}\right)$ indices and species richness were shown graphically in Fig. 2.
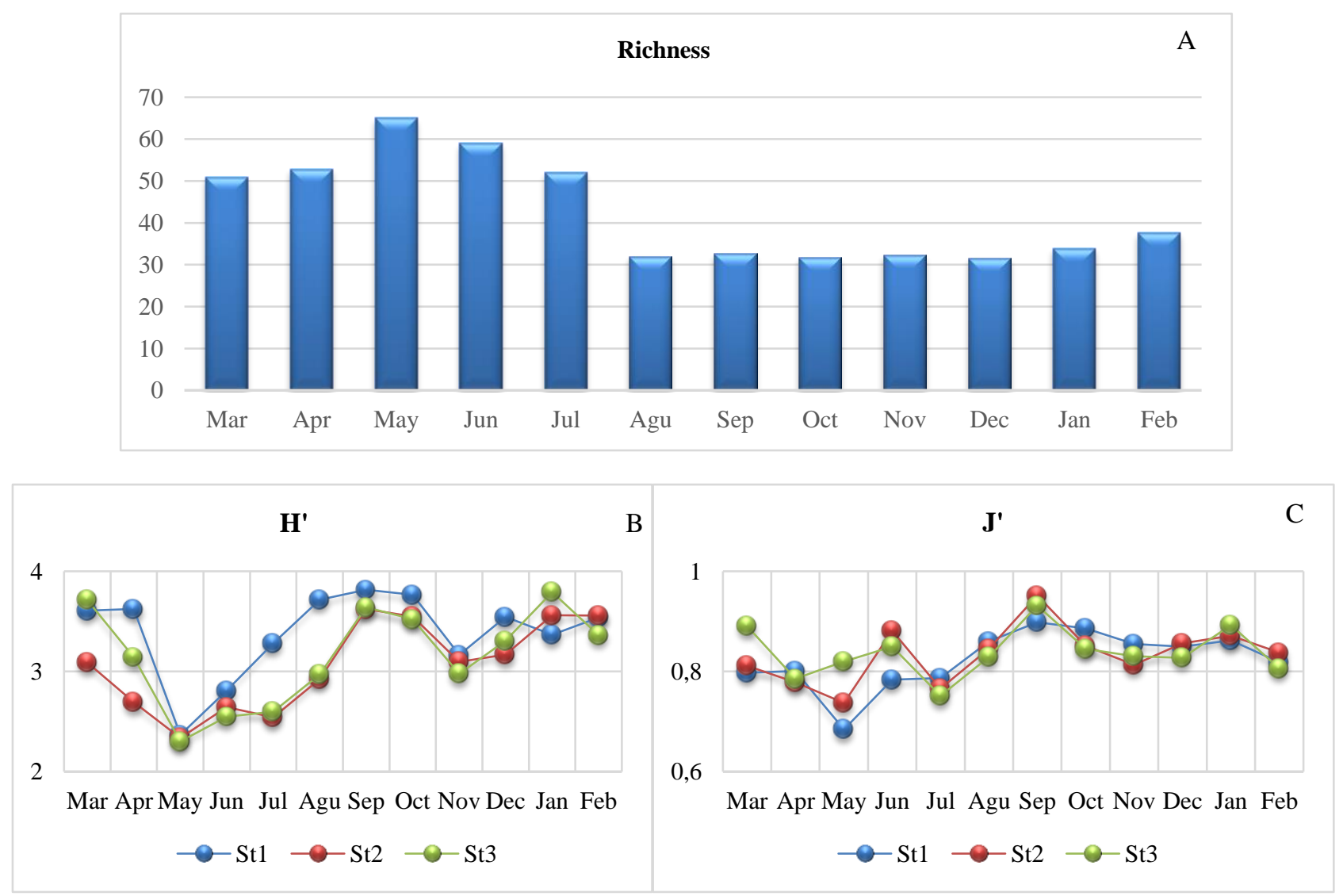

Fig. 2. Graphical representation of A) species richness and B) diversity and C) evenness indexes. The sampling months were given as abbreviations. 
Table 1. Epilithic diatom list of Taşmalı Pond.

Phylum: Bacillariophyta

Class: Bacillariophyceae

Order: Mastogloiales

Achnanthes brevipes C.Agardh

Achnanthes coarctata (Bréb. ex W.Sm.) Grunow

Mastogloia baltica Grunow

Order: Cocconeidales

Achnanthidium exiguum (Grunow) Czarnecki

Achnanthidium minutissimum (Kütz.) Czarnecki

Order: Bacillariales

Hantzschia amphioxy (Ehrenb.) Grunow

Nitzschia acicularis (Kütz.) W.Sm.

Nitzschia dissipata (Kütz.) Rabenh.

Nitzschia gracilis Hantzsch

Nitzschia palea (Kütz.) W.Sm.

Nitzschia recta Hantzsch ex Rabenh.

Nitzschia sigmoidea (Nitzsch) W.Sm.

Cymbella affinis Kütz.

Order: Cymbellales

Cymbella sp.

Encyonema silesiacum (Bleisch) D.G.Mann

Gomphonema affine Kütz.

Gomphonema gracile Ehrenb.

Gomphonema parvulum (Kütz.) Kütz.

Placoneis clementis (Grunow) E.J.Cox

Order: Fragilariales

Fragilaria capucina Desmaz.

Fragilaria capucina var. gracilis (Oestrup) Hustedt

Order: Licmophorales

Ulnaria ulna (Nitzsch) Compère

Order: Naviculales

Craticula halophila (Grunow) D.G.Mann

Diploneis parma Cleve

Gyrosigma acuminatum (Kütz.) Rabenh.

Halamphora veneta (Kütz.) Levkov

Luticola mutica (Kützing) D.G.Mann

Luticola nivalis (Ehrenb.) D.G.Mann

Luticola ventricosa (Kütz.) D.G.Mann

Navicula cari Ehrenb.

Navicula cincta (Ehrenb.) Ralfs

Navicula cryptocephala Kütz.

Navicula rhynchocephala Kütz.

Navicula trivialis Lange-Bert.

Navicula veneta Kütz.

Neidium dubium (Ehenb.) Cleve

Sellaphora pupula (Kütz.) Mereschk.

Order: Surirellales

Surirella amphioxys W.Sm.

Surirella angusta Kütz.

Surirella librile (Ehrenb.) Ehrenb.

Surirella minuta Bréb. ex Kütz.

Surirella ovalis Bréb.

Order: Thalassiophysales

Amphora ovalis (Kütz.) Kütz.

Class: Mediophyceae

Order: Stephanodiscales

Cyclotella meneghiniana Kütz.

Cyclotella sp.

Pantocsekiella ocellata (Pant.) Kiss \& Acs
According to the Regulation on the Management of Surface Water Quality Directives "Republic of Turkey, Ministry of Forestry and Water Affairs, 2015", the water bodies of all stations in Spring/Winter and Summer/Fall seasons have been identified as Class III and Class IV, polluted areas respectively. According to Trophic Classification System Limit Values in the directive, the water body of Taşmanlı Pond is in the limit values from mesotrophic to eutrophic waters. Index values of measured based on the sampled epilithic diatoms were given Table 3.

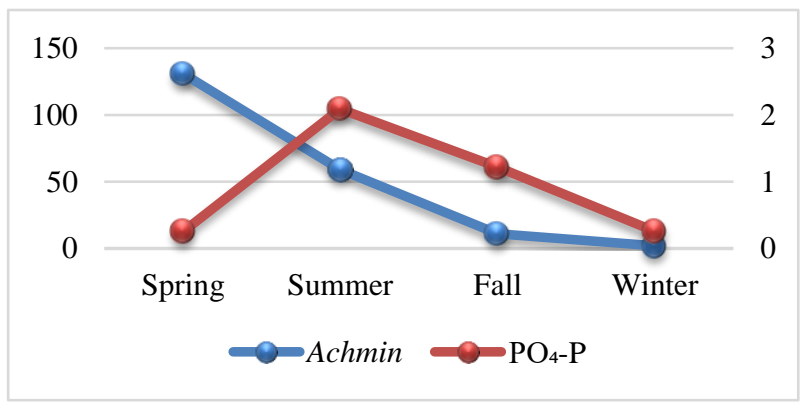

Fig. 3. The relationship between phosphate $\left(\mathrm{PO}_{4}-\mathrm{P}\right)$ values determined in the pond with respect to seasons and the abundance of Achnanthidium minutissimum (Achmin).

Table 2. The minimum, maximum and average values of the measured physic-chemical parameters of surface water in all sampling stations.

\begin{tabular}{lrrr}
\hline \hline \multicolumn{1}{c}{ Parameter } & Min. & Max. & \multicolumn{1}{c}{ Average } \\
\hline \hline Dissolved $\mathrm{O}_{2}\left(\mathrm{mgL}^{-1}\right)$ & 5.40 & 15.62 & $9.88 \pm 3.32$ \\
$\mathrm{pH}$ & 7.28 & 9.06 & $8.14 \pm 0.56$ \\
Alkalinity $\left(\mathrm{mgL}^{-1}\right)$ & 12.20 & 109.80 & $49.26 \pm 0.62$ \\
Chloride $\left(\mathrm{mgL}^{-1}\right)$ & 46.40 & 72.70 & $59.24 \pm 7.18$ \\
Temperaturew $\left({ }^{\circ} \mathrm{C}\right)$ & 6.00 & 26.00 & $15.00 \pm 7.37$ \\
Nitrate $\left(\mathrm{mgL}^{-1}\right)$ & 0.17 & 1.46 & $0.52 \pm 0.44$ \\
Phosphate $\left(\mathrm{mgL}^{-1}\right)$ & 0.14 & 2.97 & $0.98 \pm 0.12$ \\
Silica $\left(\mathrm{mgL}^{-1}\right)$ & 0.09 & 3.10 & $0.85 \pm 0.47$ \\
\hline \hline
\end{tabular}

Table 3. Index values for the sampling stations.

\begin{tabular}{lrrr}
\hline \hline & \multicolumn{1}{c}{ St.1 } & \multicolumn{1}{c}{ St.2 } & \multicolumn{1}{c}{ St.3 } \\
\hline \hline Trophic Diatom Index for Lakes (TDIL) & 1.38 & 1.42 & 1.48 \\
Lake Trophic Diatom Index (LTDI) & 76.57 & 80.17 & 75.21 \\
Ecological Quality Ratio (EQR) & 0.36 & 0.31 & 0.38 \\
\hline \hline
\end{tabular}

Table 4. Ecological Quality Ratio (EQR) class boundaries for the 3 alkalinity types (Bennion et al. 2014). LA: low alkalinity, MA: medium alkalinity, HA: high alkalinity. H: high, G: good, M: moderate, P: poor, B: bad ecological status.

\begin{tabular}{ccccc}
\hline \hline $\begin{array}{c}\text { Alkalinity type (Annual } \\
\left.\text { mean CaCO } \text { }_{\text { }} \mathbf{C L}^{-1}\right)\end{array}$ & $\mathbf{H} / \mathbf{G}$ & $\mathbf{G} / \mathbf{M}$ & $\mathbf{M} / \mathbf{P}$ & $\mathbf{P} / \mathbf{B}$ \\
\hline \hline LA $(<10)$ & 0.92 & 0.70 & 0.46 & 0.23 \\
MA (10-50) & 0.95 & 0.70 & 0.46 & 0.23 \\
HA (>50) & 0.92 & 0.70 & 0.46 & 0.23 \\
\hline \hline
\end{tabular}


Table 5. Class boundaries and trophic status according to TDIL.

\begin{tabular}{cc}
\hline \hline Class boundary & Ecological status \\
\hline \hline $4-5$ & Excellent \\
$3<4$ & Good \\
$2<3$ & Medium \\
$1<2$ & Tolerable \\
$0<1$ & Bad \\
\hline \hline
\end{tabular}

\section{Discussion}

Achnanthidium minutissimum (Kütz.) Czarnecki, was described as the most common and abundant diatom in well-oxygenated, neutral or alkaline lakes and streams with low or moderate concentrations of nutrients and organic pollution. It can also be present in high numbers in streams exposed to heavy metal pollution and in eutrophic inland waters (Bennion et al. 2014, StengerKovács et al. 2007, Kelly et al. 2005). Some former studies suggested that taxa in the A. minutissimum complex can be assigned to morphological groups, each with differing ecological preferences though these morphological groups are not discontinuous (Potapova and Hamilton 2007). However, palaeoecological works indicates that a slightly change in planktonic diatoms suggest the early stages of nutrient enrichment rather than changes in non-planktonic diatoms (Bennion et al. 2004). Indeed, as revealed in the present study, A. minutissimum became a dominant species in spring months when the pond water began to be enriched with nutrients (Fig. 3). Cyclotella meneghiniana Kütz., Gyrosigma acuminatum (Kütz.) Rabenh., Luticola mutica (Kütz.) D.G.Mann,

\section{References}

1. Akbulut, N. Akbulut, A. Günsel, S. and Solak, C.N. 2010. Use of epilithic diatoms to evaluate water quality of Kizllırmak River. Hacettepe University Fund, No: 0701601006, final report [in Turkish].

2. Anonymous. 2000. Water Framework Directive (WFD). Directive 2000/60/EC, The European Parliament and European Council.

3. Anonymous. 2015. Regulation on the Management of Surface Water Quality in Turkey (RMSWQT). Republic of Turkey, Ministry of Forestry and Water Affairs.

4. APHA.1998. Standard Methods for the Examination of Water and Wastewater. 20th ed., Washington.

5. Barlas, M. Mumcu, M.F. Dirican, S. and Solak, C.N. 2001. Sarıçay (Milas)'da yaşayan epilitik diyatomelerin su kalitesine bağlı olarak incelenmesi, 5-8 Ekim 2001 Bodrum.IV. Ulusal Ekoloji ve Çevre Kongresi.

6. Barlas, M. Mumcu, M.F. Solak, C.N. and Çoban, O. 2002. Akçapınar Deresi ve Kadın Azmağı Deresi (Muğla) epilitik alg florasının su kalitesine bağlı olarak incelenmesi. 4-7 Eylül 2002 Malatya VI. Ulusal Biyoloji Kongresi.

7. Bennion, H., Fluin, J. \& Simpson, G. L. 2004. Assessing Eutrophication and Reference Conditions for Scottish Freshwater Lochs Using Subfossil Diatoms. Journal of Applied Ecology, 41: 124-138.

8. Bennion, H., Kelly, M. G., Juggins, S., Yallop, M. L., Burgess, A., Jamieson, J. \& Krokowski, J. 2014.
Sellaphora pupula (Kütz.) Mereschk., Navicula rhynchocephala Kütz., N. cryptocephala Kütz., N. veneta Kütz., $N$. trivialis Lange-Bert., $N$. cincta (Ehrenb.) Ralfs, Gomphonema parvulum (Kütz.) Kütz., Nitzschia palea (Kütz.) W.Smith, N. gracilis Hantzsch, and N. acicularis (Kütz.) W.Smith were detected as constant species of Taşmanlı pond. According to the literature the species listed above were pollution-tolerant and they were found in eutrophic and mesotrophic waters (Taylor et al. 2007, Kelly et al. 2005, Van Dam et al. 1994, Hall et al. 1999).

The common goal of both WFD and RMSWQT is to obtain water bodies with better ecological status. According to RMSWQT directives, the pond water were classified as III-IV quality class and the trophic status change from mesotrophic to eutrophic. Significant correlation was determined between LTDI (Lake Trophic Diatom Index) and EQR (Ecological Quality Ratio). The values of TDIL, LTDI and EQR indicate that the pond water have class III (poor, moderately polluted site) water quality. Consequently, it can be said that The Taşmanlı Pond is under pollution effect and diatom community content is closely related with water quality. Therefore, the epilithic diatom metrics can be used in monitoring in Taşmanlı Pond.

\section{Acknowledgement}

A part of this work was presented as a summary note in Ecology 2017 International Symposium held in Kayseri, TURKEY on 11-13 May- 2017.

Assessment of Ecological Status in UK Lakes Using Benthic Diatoms. Freshwater Science, 33(2): 639-654.

9. Brummitt, R.K. \& Powell, C.E. 1992. Authors of Plant Names. A List of Authors of Scientific Names of Plants, With Recommended Standard Forms of Their Names, Including Abbreviations. Royal Botanic Gardens, Kew: Pp [4],732 p. ISBN: 0-947643-44-23.

10. Clarke, K.R. 1993. Non-Parametric Multivariate Analyses of Changes in Community Structure. Australian Journal of Ecology, 18: 117-143.

11. Dalkıran, N. Karacaoğlu, N. Dere, Ş. and Şentürk, E. 2008. Orhaneli Çayı'nın Kirlilik Düzeyinin Diyatomelere Dayandırılarak Saptanması. 23-27 Haziran, 19. Ulusal Biyoloji Kongresi Özet Kitapçı̆̆ı, 228. sayfa, Trabzon.

12. Della Bella, V., Puccinelli, C., Marcheggiani, S. \& Mancini, L. 2007. Benthic diatom communities and their relationship to water chemistry in wetlands of central Italy. In Annales de Limnologie-International Journal of Limnology (Vol. 43, No. 2, pp. 89-99). EDP Sciences.

13. Hall, R. I., Smol, J. P., \& Smol, J. P. 1999. Diatoms as indicators of lake eutrophication. The diatoms: applications for the environmental and earth sciences, 128168.

14. Gönülol, A. 2017. Turkishalgae Electronic Publication, Samsun, Turkey. http://turkiyealgleri.omu.edu.tr Date accessed: Jun 2017 
15. Guiry, M.D. \& Guiry, G.M. 2017. AlgaeBase. World-wide electronic publication, National University of Ireland, Galway. www.algaebase.org Date accessed: 15 Jun 2017, $16 \mathrm{p}$.

16. Gümüş, F. 2010. Taşmanlı Göleti (Sinop) Kıyı Bölgesi Algleri Üzerine Nitel ve Nicel Araștırmalar. Ondokuz Mayıs Üniversitesi, Fen Bilimleri Enstitüsü, Yüksek Lisans Tezi, 48 p. Samsun.

17. Gürbüz, H. and Kıvrak, E. 2002. Use of epilithic diatoms to evaluate water quality in the Karasu River of Turkey. $J$. Environmental Biology, 23(3): 239-246.

18. Hajnal, É., Stenger-Kovács, C. \& Padisák, J. 2009. DILSTORE Software for Ecological Status Assessment of Lakes Based on Benthic Diatoms. Fottea, 9: 351-354.

19. Kalyoncu, H. 2002. Aksu Çayı'nın Fiziksel, Kimyasal ve Biyolojik Olarak Incelenmesi. Doktora Tezi. S.D.Ü. Fen Bilimler Enstitüsü, Isparta, $155 \mathrm{~s}$.

20. Kalyoncu, H. Çiçek, N.L. Akköz, C. and Yorulmaz, B. 2009. Comparative performance of diatom indices in aquatic pollution assessment. African Journal of Agricultural Research, 4(10): 1032-1040.

21. Karacaoğlu, N. Dalkıran, N. Dere, Ş. and Şentürk, E. 2008. Emet Çayı'nın Kirlilik Düzeyinin Diyatomelere Dayandırılarak Saptanması. 23-27 Haziran, 19. Ulusal Biyoloji Kongresi Özet Kitapçığı, 228. sayfa, Trabzon.

22. Kelly, M. G., Bennion, H., Cox, E. J., Goldsmith, B., Jamieson, J., Juggins, S., Mann, D.G. \& Telford, R. J. 2005. Common Freshwater Diatoms of Britain and Ireland: An Interactive Key. Environment Agency, Bristol.

23. Krammer, K. \& Lange-Bertalot, H. 1991a. Bacillariophyceae, Band, 2/3 3,. Teil :Centrales, Fragillariaceae, Eunotiaceae. Gustav Fischer-Verlag, Stuttgart, $576 \mathrm{pp}$.

24. Krammer, K. \& Lange-Bertalot, H. 1991b. Süßwasserflora von Mitteluropa Bacillariophyceae, Band, 2/4 4,. Teil:Acnanthaceae, Kritische Erganzungen zu Navicula (Lineolatae) und Gomphonema Gesamtliteraturverzeichnis. Gustav Ficher- Verlag, Stuttgart, 437 pp.

25. Krammer, K. \& Lange-Bertalot, H. 1999a. Süßwasserflora von Mitteluropa Bacillariophyceae, Band 2/1, 1.Teil :Naviculaceae. Spectrum Academischer-Verlag, Heidelberg, Berlin.

26. Krammer, K. \& Lange-Bertalot, H. 1999b. Süßwasserflora von Mitteluropa Bacillariophyceae, Band 2/2, 2.Teil: Bacillariaceae, Epithemiaceae, Surirellaceae. Spectrum Academischer -Verlag, Heidelberg, Berlin.

27. Kelly, M.G. \& Whitton, B.A. 1995. The Trophic Diatom Index: A New İndex for Monitoring Eutrophication in Rivers. Journal of Applied Phycology, 7: 433-444.

28. Pielou, E.C. 1975. Ecological Diversity. John Wiley and Sons, New York, 165 p.

29. Potapova, M., and P. B. Hamilton. 2007. Morphological and ecological variation within the Achnanthidium minutissimum (Bacillariophyceae) species complex. Journal of Phycology 45:561-575.
30. Renberg, I. 1990. A Procedure for Preparing Large Sets of Diatom Slides from Sediment Cores. Journal of Paleolimnology, 4: 87-90.

31. Round, F.E. 1953. An Investigation of Two Benthic Algal Communites in Malharm Tarn, Yorkshire. Journal of Ecology, 41:174-197.

32. Round, F.E., Crawford, R.M. \& Mann, D.G. 1990. The Diatoms: Biology and Morphology of the Genera. Cambridge University Press, Cambridge, 746 p.

33. Shannon, C.E. \& Weaver W. 1949. The Mathematical Theory of Communication. Univ. Of Illionis Press, Urbana, $144 \mathrm{p}$.

34. Sims P.A. (1996). An Atlas of British Diatoms. Biopress Ltd., England, $601 \mathrm{~s}$.

35. Solak, C.N. 2009. The Determination of Pollution in Felent Stream by using Some Aquatic Organisms. Ph.D. Thesis, Dumlupınar University, 143pp [in Turkish].

36. Solak, C.N. 2011. The application of diatom indices in the Upper Porsuk River, Kütahya-Turkey. Turkish Journal of Fisheries and Aquatic Sciences, 11(1): 31-36.

37. Solak, C.N. Fehér, G. Barlas, M. and Pabuçcu, K. 2007a. Use of epilithic diatoms to evaluate water quality of Akçay Stream (Büyük Menderes River) in Mugla/Turkey. Archiv Für Hydrobiologie Suppl., 161 (3-4), Large Rivers, 17 (34): $327-338$.

38. Solak, C.N. Ács, É. and Pabuçcu, K. 2007b. BDI (Biyolojik Diyatome İndeksi) İndeksine Göre Düden Şelalesi (Antalya) Su Kalitesinin Durumu. 10-13 Eylül 2007 Malatya 7. Ulusal Ekoloji ve Çevre Sempozyumu Özet Kitapçı̆̆ 184 s.

39. Solak, C.N. Àcs, É. and Dayioglu, H. 2009. The application of diatom indices in Felent Creek (Porsuk-Kütahya). Diatomededlingen, 33: 107-109.

40. Solak, C.N. \& Ács, É. 2011. Water Quality Monıtorıng in European and Turkish Rivers Using Diatoms. Turkish Journal of Fisheries and Aquatic Sciences, 11(2): 329-337.

41. Stenger-Kovács, C., Buczko, K., Hajnal, E. \& Padisák J. 2007. Epiphytic, Littoral Diatoms as Bioindicators of Shallow Lake Trophic Status: Trophic Diatom Index for Lakes (TDIL) Developed in Hungary. Hydrobiologia, 589(1): 141-154.

42. Taylor, J.C., Harding, W.R. \& Archibald, C.G.M. 2007. An Illustrated Guide to Some Common Diatom Species from South Africa. Pretoria: Water Research Commission, $225 \mathrm{p}$.

43. Van Dam, H., Mertens, A. \& Sinkeldam, J. 1994. A coded checklist and ecological indicator values of freshwater diatoms from the Netherlands. Aquatic Ecology, 28(1): 117-133.

44. WFD-UKTAG, 2014. Phytobenthos - Diatoms for Assessing River and Lake Ecological Quality (DARLEQ2). Water Framework Directive - United Kingdom Technical Advisory Group (WFD-UKTAG), Scotland. 